\title{
Lithic technology of an Itaparica industry archaeological site: the Gruta das Araras rockshelter, Midwest Brazil
}

\author{
João Carlos Moreno de Sousa
}

Museu Nacional, Universidade Federal do Rio de Janeiro, Quinta da Boa Vista s/n, Rio de Janeiro, Brazil.

Email: jcmorenodesousa@gmail.com

\begin{abstract}
:
The Itaparica tradition is a lithic industry largely known with evidences of its presence in sites all over Brazil's Central Plateau. Its main characteristic is the overwhelming presence of unifacially retouched artifacts (limaces) in these sites during the Pleistocene-Holocene transition and Early Holocene. Previous researches confirm the technological similarity of the limaces between some of these sites. This paper presents a technological analysis of the flaking residues of one of these sites: The Grutas das Araras Rockshelter, in which the oldest levels were interpreted as a lithic workshop.
\end{abstract}

Keywords: Brazilian archaeology; Itaparica tradition; lithic technology; Pleistocene-Holocene transition

\section{Introduction}

The Itaparica tradition was first defined by the Programa Nacional de Pesquisas Arqueológicas (Archaeological Researches National Program, a.k.a PRONAPA), which happened in Brazil during the 1960 e 1970 decades, based on researches carried out by Valentin Calderón, in the 1960's, in Bahia and Pernambuco states. Calderón (1973) reported the presence of prehistoric human groups that produced lithic artifacts - which would be later considered as plan-convex unifacial tools with similar forms and shapes - in the Gruta do Padre rockshelter site, in the Itaparica region, Pernambuco state. The lithic material was dated to $7.580 \pm 410 \mathrm{AP}$ (cal. $8.493 \pm 454 \mathrm{AP}$ ). (All calibrated dates presented in this paper were calculated with CalPal2007_HULU calibration curve by CalPal Online, last accessed January 2014).

Years later, Schmitz (1980) noted similarity between the lithic materials found in Serranópolis region, Goiás State, with the lithic material reported by Calderón. Because of this similarity, Schmitz determined the lithic material found in Serranópolis region sites were from an ancient tradition, as he called for the first time, the Itaparica tradition. Based in the presence of these plan-convex unifacial artifacts, Brazilian researchers labeled as Itaparica tradition several archaeological sites located in the Brazilian central plateau, from Northeast to Middle-West of the country (Figure 1) dated from Pleistocene-Holocene transition and Early Holocene.

Published by the School of History, Classics and Archaeology, University of Edinburgh ISSN: 2055-0472. URL: http://journals.ed.ac.uk/lithicstudies/

This work is licensed under a Creative Commons Attribution 2.5 UK: Scotland License. 


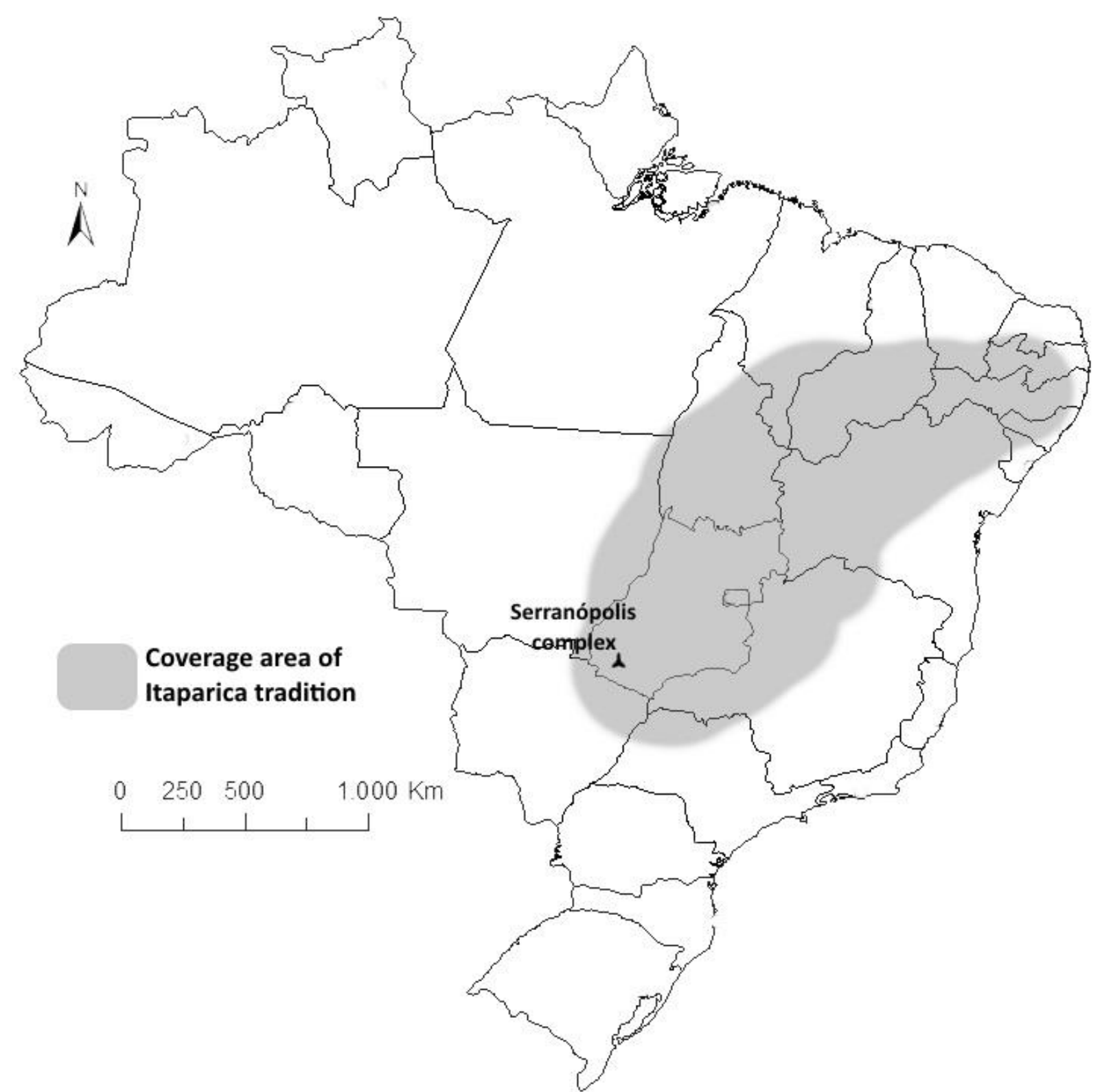

Figure 1. Map of Brazil with the researched location and the coverage area of Itaparica tradition.

The term limace has been used to refer to this plan-convex unifacial artifact, since its form and shape is similar to the old world artifacts. Because of its form and shapes, every plan-convex artifact unifacially flaked was called limace, so the archaeological sites where they were found were classified as Itaparica tradition.

In the last decades the validity of the use of Itaparica tradition term started to be questioned, because of its alleged presence in a very large geographic area, and because of the word tradition, which was already being (conf)used to refer to ethnic groups. Some researches, using the technological approach, started to ask if these limaces were, actually, just similar products in forms and shapes produced by different flaking methods and technics.

Recently, some researches proved that these limaces, once rated in the same morphological package, have technological variability (Fogaça 2001; Fogaça \& Lourdeau 2008; Lourdeau 2010; 2012). However, despite the critics over previous analysis, the presence of limaces occurring in a large area during the Pleistocene-Holocene transition is incontestable. According to Lourdeau (2010), who studied the technology of limaces found in 
Serra da Capivara region (Pica-Pau site and Pedra Furada site) and Serranópolis region (Diogo Lemes site), the technological similarity really exists in those Itaparica labeled sites. Lourdeau, avoiding the use of the term tradition, reported the existence of a technocomplex in those sites.

The use of the word limace, as used by Lourdeau (2010), is nowadays limited, by definition, to the artifacts produced on blade-like flakes by unifacial reduction (façonnage) opposed to a plan face. The presence of the Itaparica lithic industry all over the Brazil Central Plateau between 13k 9k BP is now largely accepted by Brazilian archaeologists. Gruta das Araras rockshelter is one of these sites.

Avoiding a higher debate about the use of the terms "archaeological tradition"; "archaeological culture" or "technocomplex" I'll use the term Itaparica industry to refer to these entirety of lithic assemblages that presents this assumed same technological features.

\subsection{Previous research}

Serranópolis archaeological complex area was first researched by Pedro Ignácio Schmitz during the 1970's within the Goiás State Archaeological Program. The excavated material is now in Anchietano Research Institute (IAP), Rio dos Sinos University (UNISINOS).

The first fieldwork season was carried out in 1975, and excavations were done until 1982. The program aimed to study the archaeology of Goiás state, focusing mostly in chronological, distributional and ecological elements (Schmitz et al. 1989).

That research program followed the same previous PRONAPA methods, and by following those methods the Serranópolis sites were classified in traditions. The site was excavated by $10 \mathrm{~cm}$ arbitrary levels. Since then no excavations were carried out in Gruta das Araras rockshelter.

According to Rodet et al (2011) Technological analysis of the Gruta das Araras lithic vestiges were carried out. However, the results were never published.

Lourdeau $(2010 ; 2012)$ analyzed the Diogo Lemes rockshelter site, located at the same archaeological sites complex. However, his research focused on the cores and tools. This paper shows the results on lithic residues - flakes - analysis.

\section{Site characterization}

Gruta das Araras rockshelter (also known as GO-JA-03 site) is located near the city of Serranópolis, southeast Goiás, and presents the following dates (Table 1) (Schmitz et al. 2004):

Table 1. Gruta das Araras site dates. Bold date related to analyzed material.

\begin{tabular}{lclcc}
\hline Level & Sample & Material & C14 Date & $\begin{array}{c}\text { Calibrated Date } \\
\text { (CalPal Online) }\end{array}$ \\
\hline $150-160 \mathrm{~cm}$ & SI-3109 & Charcoal & $5.720 \pm 50 \mathrm{BP}$ & $6.530 \pm 70 \mathrm{BP}$ \\
$210-220 \mathrm{~cm}$ & SI-3110 & Charcoal & $9.765 \pm 75 \mathrm{BP}$ & $11.163 \pm 74 \mathrm{BP}$ \\
\hline
\end{tabular}

However, there are deeper undated arbitrary levels (until $240 \mathrm{~cm}$ ) with more lithic materials. Also, there are ancient dated sites at the same archaeological complex area, like Diogo Lemes rockshelter (also known as GO-JA-01 site), dated at $10.580 \pm 115 \mathrm{BP}$ (cal $12.466 \pm 206$ ); and GO-JA-04 site, dated at 10.740 $\pm 85 \mathrm{BP}$ (cal 12.720 \pm 77 ) (Table 2).

In Gruta das Araras site were found not just lithics, but in the youngest levels were also found pottery fragments and two preserved human burials, with one skeleton in each one. The Itaparica industry is identified, however, just in the oldest levels of Serranópolis complex sites, and as usual, because of the large presence of the limaces. Gruta das Araras rockshelter 
does not have a large presence of limaces, but a larger evidence of production residues by flaking - the flakes themselves. Just one limace was found and it is in the same dated level.

Table 2. Pleistocene-Holocene dates at Serranópolis archaeological complex. Bold date related to analyzed material in this research.

\begin{tabular}{|c|c|c|c|c|}
\hline Sample & Material & Site & C14 Date & $\begin{array}{l}\text { Calibrated Date } \\
\text { (CalPal Online) }\end{array}$ \\
\hline SI-5562 & Charcoal & GO-JA-26 & $8.370 \pm 85$ & $9.365 \pm 98$ \\
\hline$N-2347$ & Charcoal & $\begin{array}{c}\text { Diogo Lemes } \\
\text { (GO-JA-01) }\end{array}$ & $8.740 \pm 90$ & $9.786 \pm 160$ \\
\hline SI-3696 & Charcoal & $\begin{array}{c}\text { Diogo Lemes } \\
\text { (GO-JA-01) }\end{array}$ & $8.805 \pm 100$ & $9.889 \pm 193$ \\
\hline SI-5563 & Charcoal & GO-JA-26 & $8.880 \pm 90$ & $9.966 \pm 164$ \\
\hline SI-3695 & Charcoal & $\begin{array}{c}\text { Diogo Lemes } \\
\text { (GO-JA-01) }\end{array}$ & $8.915 \pm 115$ & $9.983 \pm 179$ \\
\hline SI-3697 & Charcoal & $\begin{array}{c}\text { Diogo Lemes } \\
\text { (GO-JA-01) }\end{array}$ & $9.020 \pm 70$ & $10.119 \pm 115$ \\
\hline SI-3698 & Charcoal & $\begin{array}{c}\text { Diogo Lemes } \\
\text { (GO-JA-01) }\end{array}$ & $9.060 \pm 65$ & $10.235 \pm 47$ \\
\hline SI-3107 & Charcoal & GO-JA-02 & $9.195 \pm 75$ & $10.382 \pm 96$ \\
\hline SI-3700 & Charcoal & $\begin{array}{c}\text { Diogo Lemes } \\
\text { (GO-JA-01) }\end{array}$ & $9.510 \pm 60$ & $10.874 \pm 157$ \\
\hline SI-3110 & Charcoal & $\begin{array}{c}\text { Gruta das } \\
\text { Araras } \\
\text { (GO-JA-03) }\end{array}$ & $9.765 \pm 75$ & $11.163 \pm 74$ \\
\hline SI-3108 & Charcoal & GO-JA-02 & $10.120 \pm 80$ & $11.718 \pm 223$ \\
\hline$N-2348$ & Charcoal & $\begin{array}{c}\text { Diogo Lemes } \\
\text { (GO-JA-01) }\end{array}$ & $10.400 \pm 130$ & $12.280 \pm 250$ \\
\hline SI-3699 & Charcoal & $\begin{array}{c}\text { Diogo Lemes } \\
\text { (GO-JA-01) }\end{array}$ & $10.580 \pm 115$ & $12.466 \pm 206$ \\
\hline SI-3111 & Charcoal & GO-JA-04 & $10.740 \pm 85$ & $12.720 \pm 77$ \\
\hline
\end{tabular}

Under the typical cerrado vegetation (Brazilian savannah) the region is rich with sandstone outcrops. The Gruta das Araras site is located under a rock shelter largely constituted by silicified sandstone, and some friable sandstone. Some areas are so metamorphosed that the rock can easily be called quartzite. The rock shelter is $80 \mathrm{~m}$ large, and 6 14 $\mathrm{m}$ deep, and presents lots of paintings and gravures.

According to Schmitz et al.. (1989), the palaeoenvironmental analysis of Diogo Lemes rockshelter points to a large dry and wet climate variation during Pleistocene-Holocene transition and early Holocene in the region.

Schmitz (2005) says the Itaparica tradition was still contemporary to megafauna, however the numerous fauna vestiges found in the Serranópolis sites represent just a typical Holocene fauna.

Seven excavations units were made in the site by Schmitz (Figure 2). The PleistoceneHolocene material presented in this article is from unit $\mathrm{C} 4$ which, according to Schmitz (personal communication with Schmitz on January 2013) had the lower risk of collapse and erosion in a deep excavation, due to the plant roots in the area. Unit C4 is a $2.5 \mathrm{~m}$ to $2.5 \mathrm{~m}$ square that reached $240 \mathrm{~cm}$ deep. 


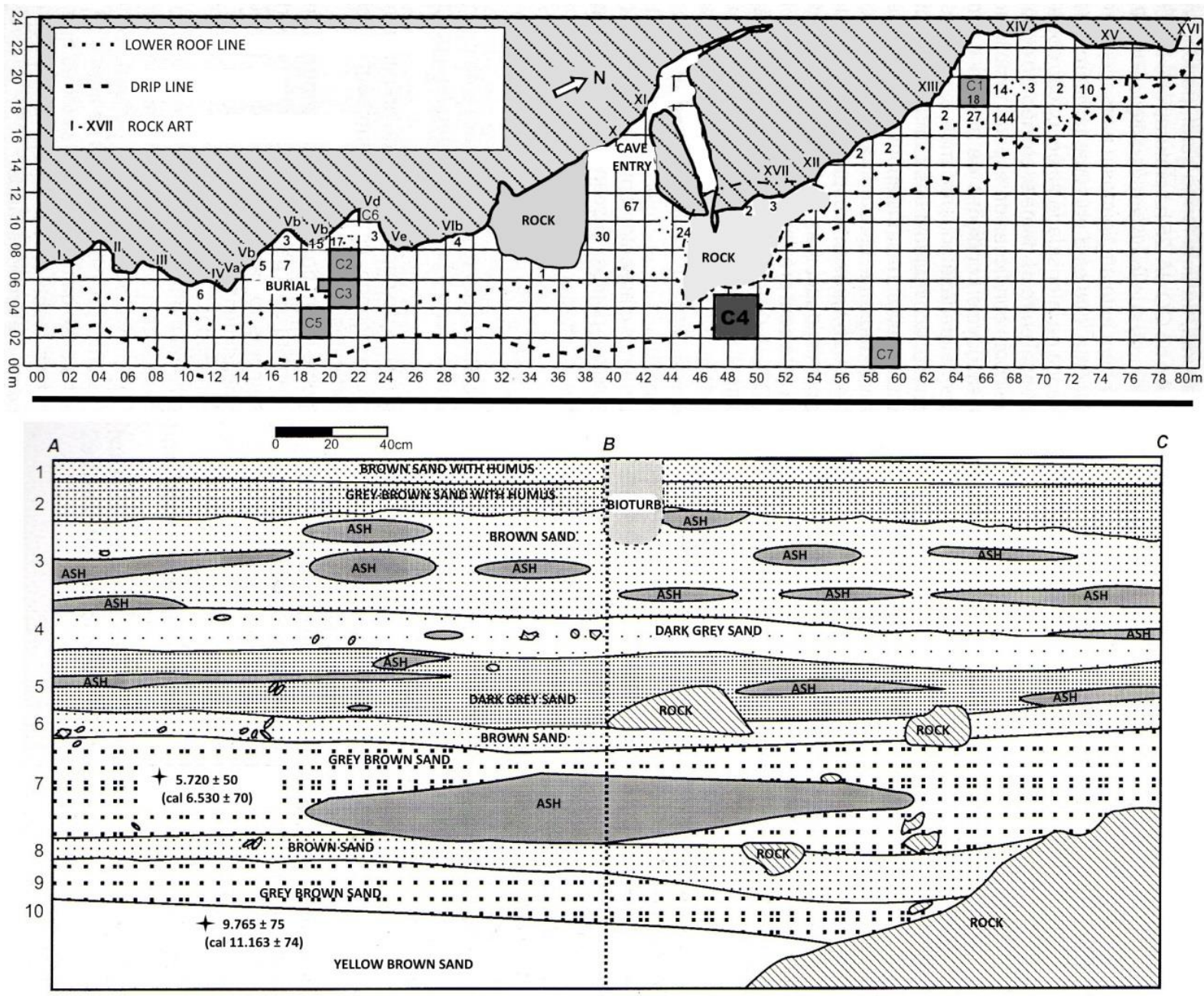

Figure 2. Upper figure: Site map representing the excavation units. Lower figure: Stratigraphy of C4 unit. Adapted from Schmitz (2004).

\section{Lithic Analysis}

\subsection{Previous Results}

Just a few analyses were done over the local lithic industry. Publications about previous analysis in Gruta das Araras rockshelter are all from Schmitz et al. (1989), with a general description of the artifacts, and Schmitz et al. (2004) with the same descriptions. These publications contains general form and shapes descriptions and quantification of the artifacts.

An analysis was made by Rodet, in the year 2007, focusing the flakes of Gruta das Araras rockshelter. Rodet looked for the specific techniques of flaking, like pressure, hard percussion, soft percussion, etc. (personal communication with Rodet on September 2011).

Another previous analysis of local industry, already cited in this paper, is the research of Antoine Lourdeau (2010) who analyzed the limaces of Diogo Lemes rockshelter.

\subsection{Material and Methods}

Only the lithics found between 200 to $240 \mathrm{~cm}$ deep were analyzed, and they consisted by the oldest lithics of the site. It includes the dated level $(200-210 \mathrm{~cm})$ and the older ones. 
The selected sample was constituted by 322 (7\% of the assemblage) unbroken flakes (lithic production residues). This choice was made because of the higher potential information that the whole flakes can convey.

The formal artifacts (the products) have all been analyzed. However, the total of broke and non-broke artifacts is just 7.

Unfortunately, the only core found in those levels could not be analyzed, since it was lost decades ago, probably during the transportation to the museum.

The applied method of analysis was strongly based in the operatory chain notion of Mauss (2003) and Leroi-Gourhan (2002), as the notions of lithic features technology of Boëda (1997), Dauvois (1976), Fogaça (2001 \& 2006), Fogaça \& Boëda (2006), Inizan et al (1995), Pelegrin (1997), Piel-Desruisseaux (1989), Rigaud (1977), Roche \& Tixier (1984), Tixier (2012), Vaughan (1983), and White \& Thomas (1972).

Statistical analyzes were made after the quantitative and qualitative analysis of the lithics features. Only the highest statistical tendencies are presented in this article.

One of the statistical observed tendencies is the coefficient of determination $\left(\mathrm{R}^{2}\right)$, which varies from 0 to $1-$ or $0 \%$ to $100 \%$. The correlation level grows as its values approaches $100 \%$, and categories were defined as suggested in Table 3.

Table 3. Correlation level categories

\begin{tabular}{cc} 
Table 3. Correlation level categories & \\
\hline Coefficient of determination & Correlation level \\
\hline $0 \%-20 \%$ & inexistent \\
$20 \%-40 \%$ & very low \\
$40 \%-50 \%$ & low \\
$50 \%-60 \%$ & average \\
$60 \%-70 \%$ & average high \\
$70 \%-80 \%$ & high \\
$80 \%-90 \%$ & very high \\
$90 \%-100 \%$ & perfect \\
\hline
\end{tabular}

\section{Results}

The oldest levels of the site point to an ancient lithic workshop. That means it was a specific area used to massive lithic artifacts production. This hypothesis is justified by the large amount of residues in comparison to the rarely found formal artifacts, whereas in other sites nearby this relation is inverted.

The local silicified sandstone is the highly predominant raw material identified, with very rare exceptions, like flint. The local silicified sandstone mix the white and red colors, with rare grey color, but the lithics of the oldest levels are, for some reason, almost always white $(68 \%)$. There are no evidences of taphonomic processes, like patina, changing the color of the flakes. The red sandstone flakes in these old levels exist, but they are rare. The flint is also rare and always red, and for some reason, it is the only raw material that seems to have some evidence of fire action. The low presence of flint makes it difficult to look for a different standard of flaking methods on flint artifacts. So, the characterization of the industry is made over the artifacts made by local raw material only - silicified sandstone.

Roughly speaking, the Gruta das Araras Rockshelter analyzed assemblage points to a large limaces production by core-flaking of thick blades and unifacial reduction and retouch.

The rock shelter itself is an excellent source of raw material. However, more excavations are necessary to look for the exact points of the rock shelter that could be used like source. Anyway, we can be sure that the raw material is local. The presence of big cortical flakes (larger than $40 \mathrm{~cm}$ ) in the assemblage is a good evidence for that. There are some big flakes 
that were not used to produce an artifact, but are evidence for core-flaking. All the operatory chain, with exception of the use and discard of the artifacts, can be seen in the assemblage

The operatory chain scheme of lithics production in oldest levels of Gruta das Araras rockshelter is shown in Figure 3.

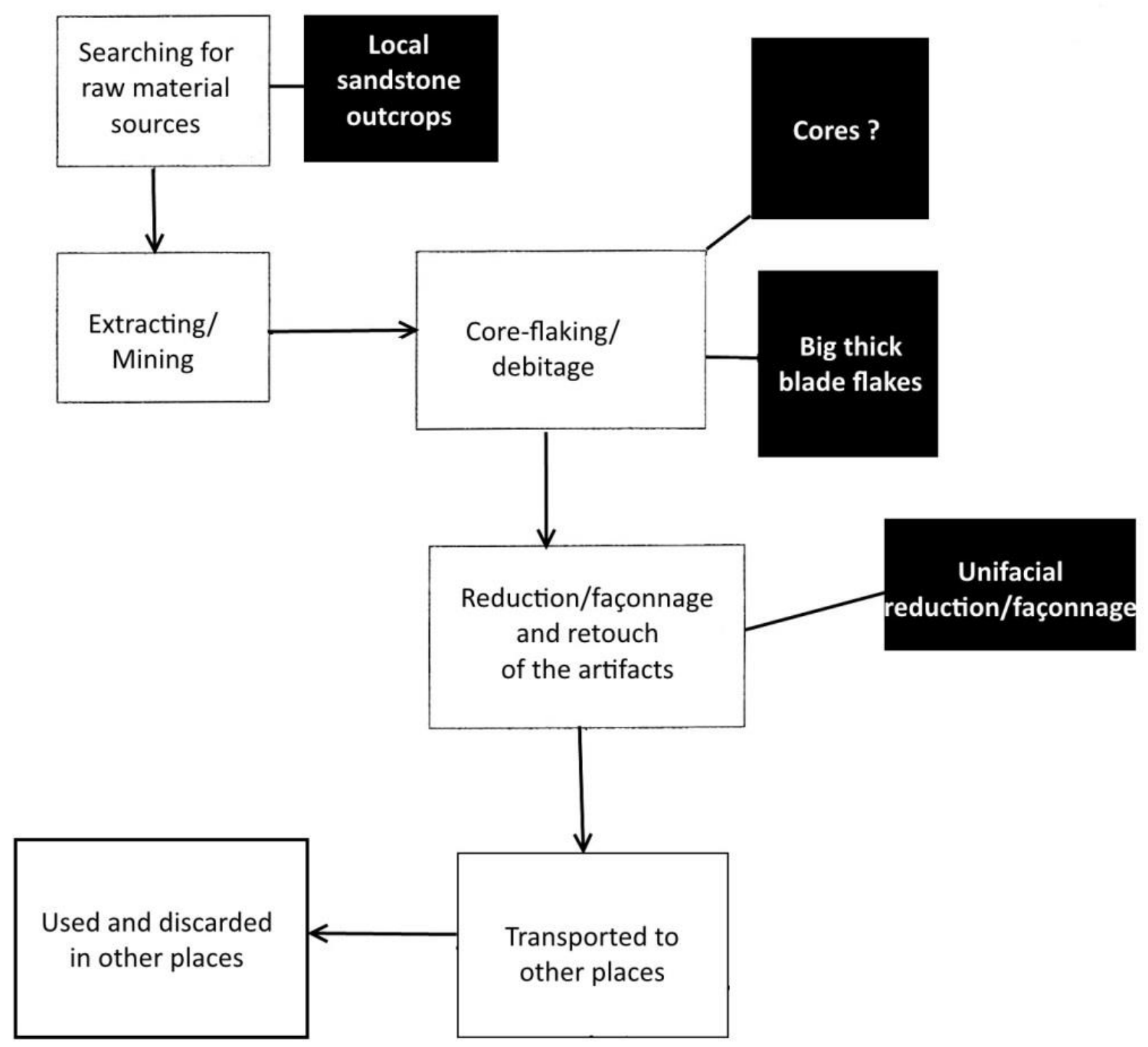

Figure 3. Operatory chain of lithic artifacts of Gruta das Araras site. White boxes represent different stages. Black boxes represent the analysed evidences.

Technological most expressive features of each production stage are presented in the following topics.

\subsection{Core-Flaking (debitage)}

There are no tendencies in the core-flakes sizes, but a statistical high $\left(\mathrm{R}^{2}=60 \%\right)$ correlation (using the coefficient of determination statistic method). between length and thickness of the flakes was identified. It means that the length and the thickness of the artifacts could be defined in the core-flaking stage, while the width of the artifact is defined in the next stages (Figure 4).

The platforms are, mostly, plan, without any kind of preparation, and do not have any clear tendencies of sizes. But there's a high statistical correlation $\left(\mathrm{R}^{2}=68 \%\right)$ between the 
length of the flakes and the thickness of the platforms (Figure 5). However, there is no correlation between the thickness of the flakes and their own platforms.

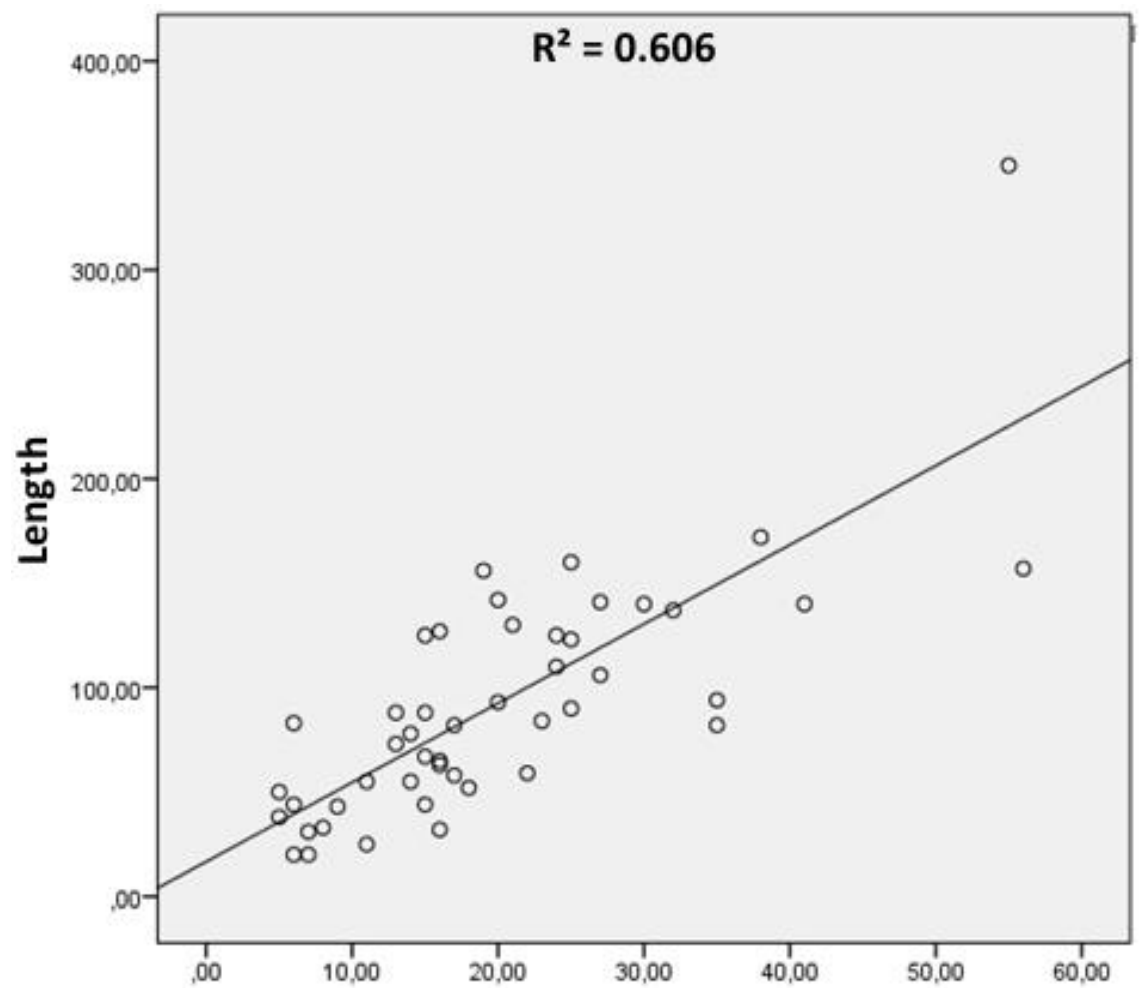

Thickness

Figure 4. Coefficient of determination: $\mathrm{R}^{2}$ Correlation of debitage/core-flakes length and thickness.

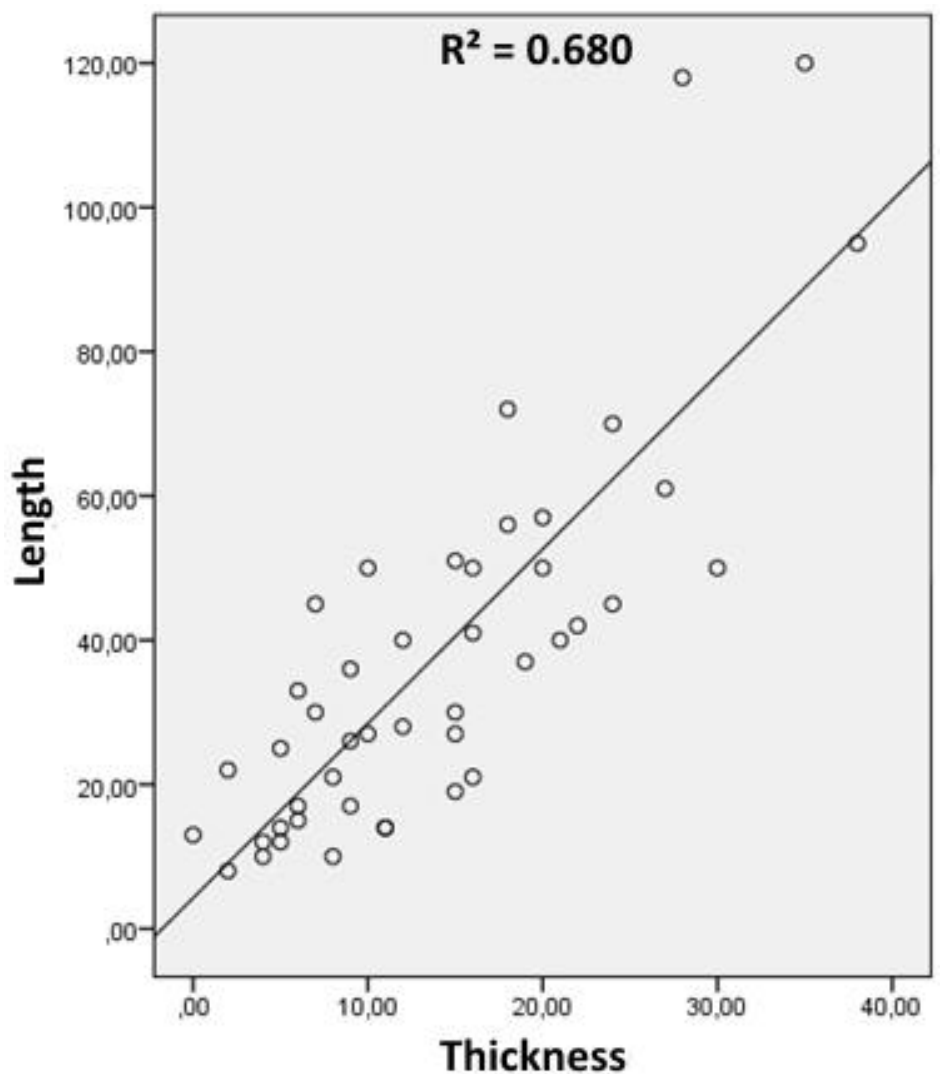

Figure 5. Coefficient of determination: $\mathrm{R}^{2}$ Correlation of debitage/core-flakes platforms length and thickness. 
More than $70 \%$ of core-flakes have no cortex. It means that a single big piece of sandstone could be used to produce a large amount of flakes. If more pieces with cortex were necessary, more flakes with any presence of cortex would be seen.

There is a tendency of core-flakes with $100^{\circ} \sim 120^{\circ}$ angles between the platform and the positive face of the flake. It means the angle of the cores platform and the surface flaking is mostly between $60^{\circ}$ and $80^{\circ}$ (Figure 6).

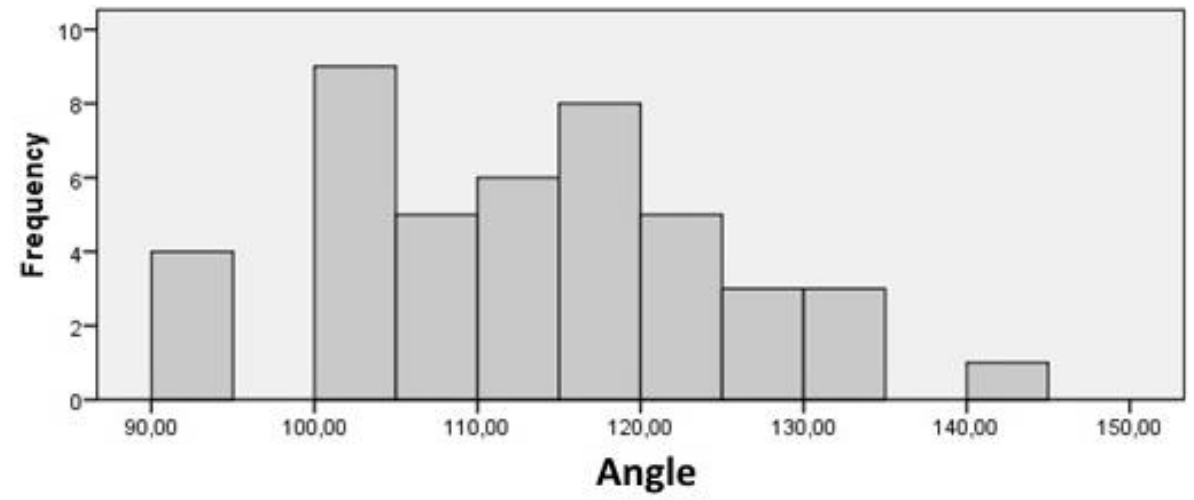

Figure 6. Debitage/core-flakes angles (platform/positive face) tendencies.

The core-flakes have almost always a flat shape. The superior face of the flakes have between 1 to 5 flake negatives, organized almost always with a vertical rib that guides de core flaking. They tend to have blade or quadrilateral forms, and some of them are reflected and overshot.

\subsection{Reduction of the artifacts (façonnage)}

The general measures of the reduction flakes are between 15-30 mm length, 10 30 mm width and 1 7 mm thick (Figures 7,8 and 9). There is no correlation between these measures.

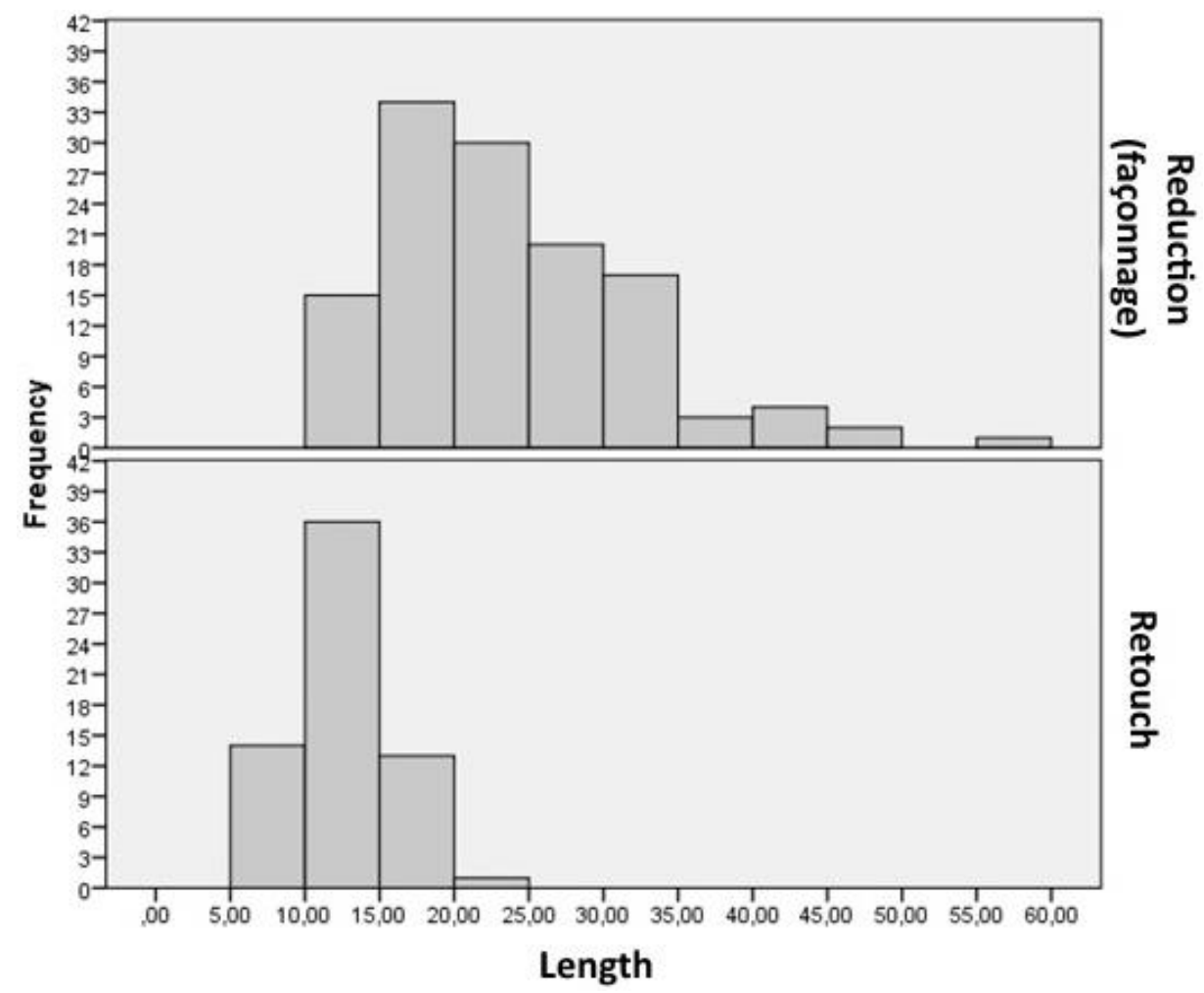

Figure 7. Reduction and retouch flake length tendencies. 


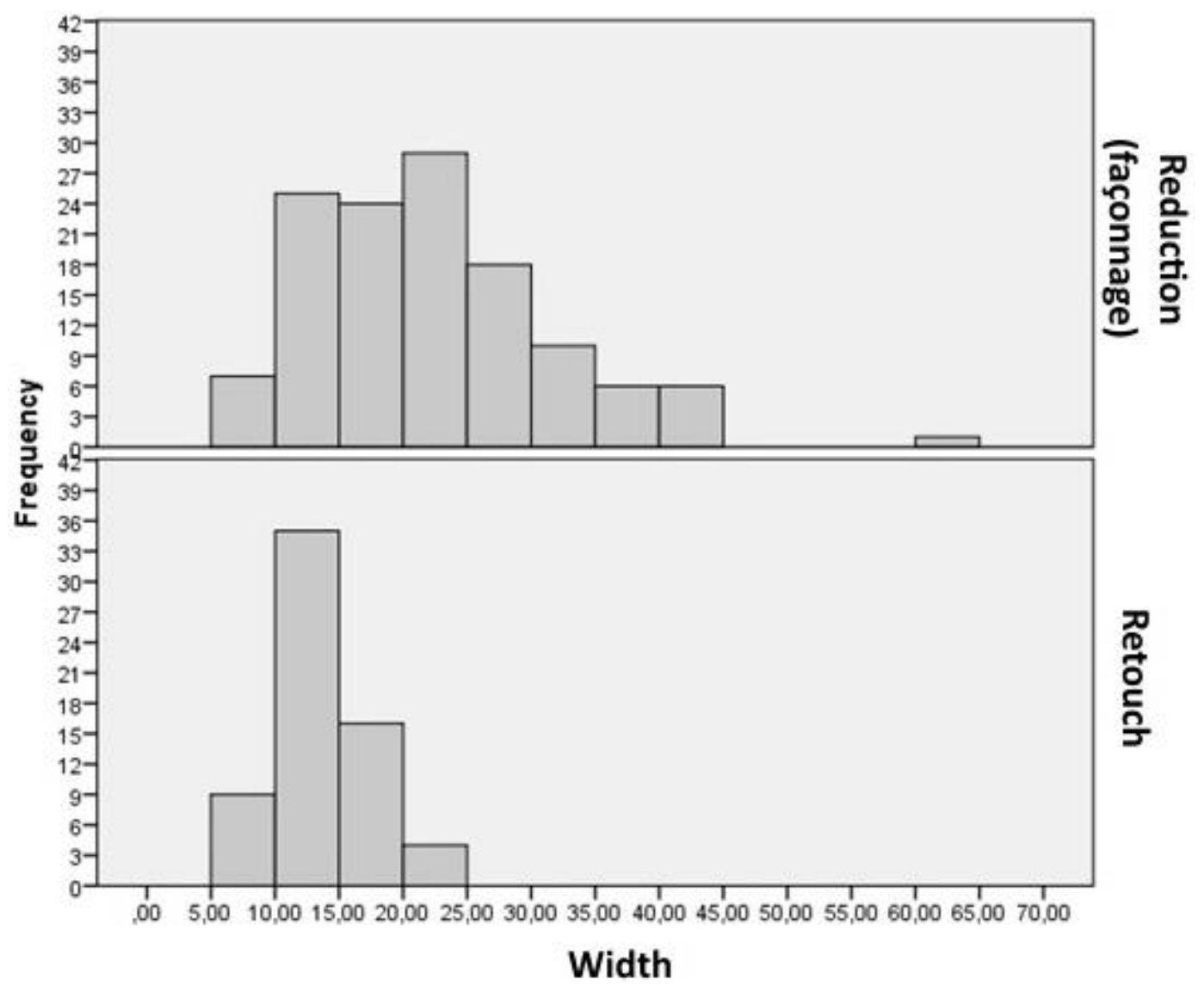

Figure 8. Reduction and retouch flake width tendencies.

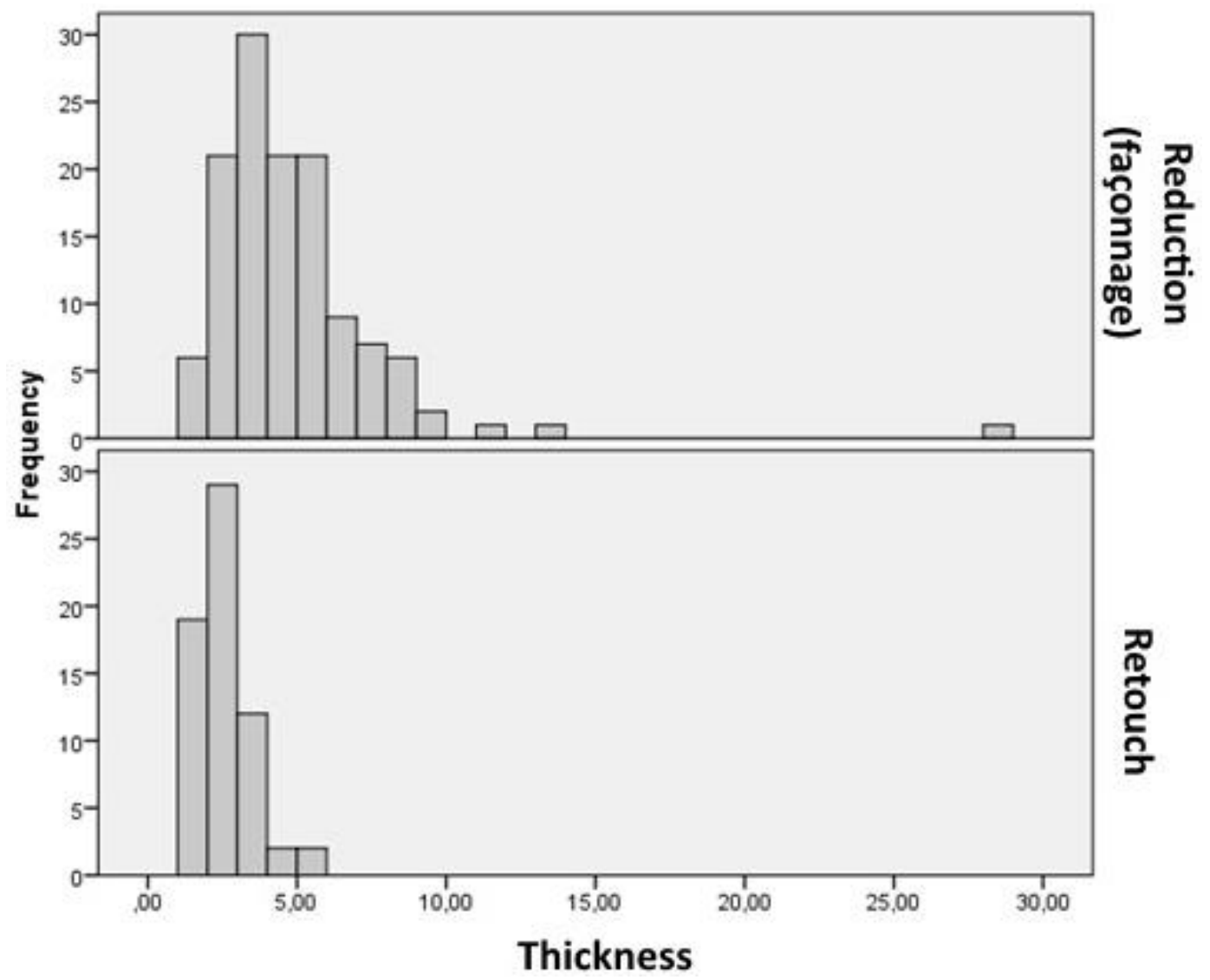

Figure 9. Reduction and retouch flake thickness tendencies. 
The flakes platforms are mostly prepared, with plan or linear surfaces. The plan platforms have round and comma shapes. Their length varies a lot, between 3 and $15 \mathrm{~mm}$, and the thickness is mostly between 0 and $3 \mathrm{~mm}$ (Figures 10, 11 and 12).

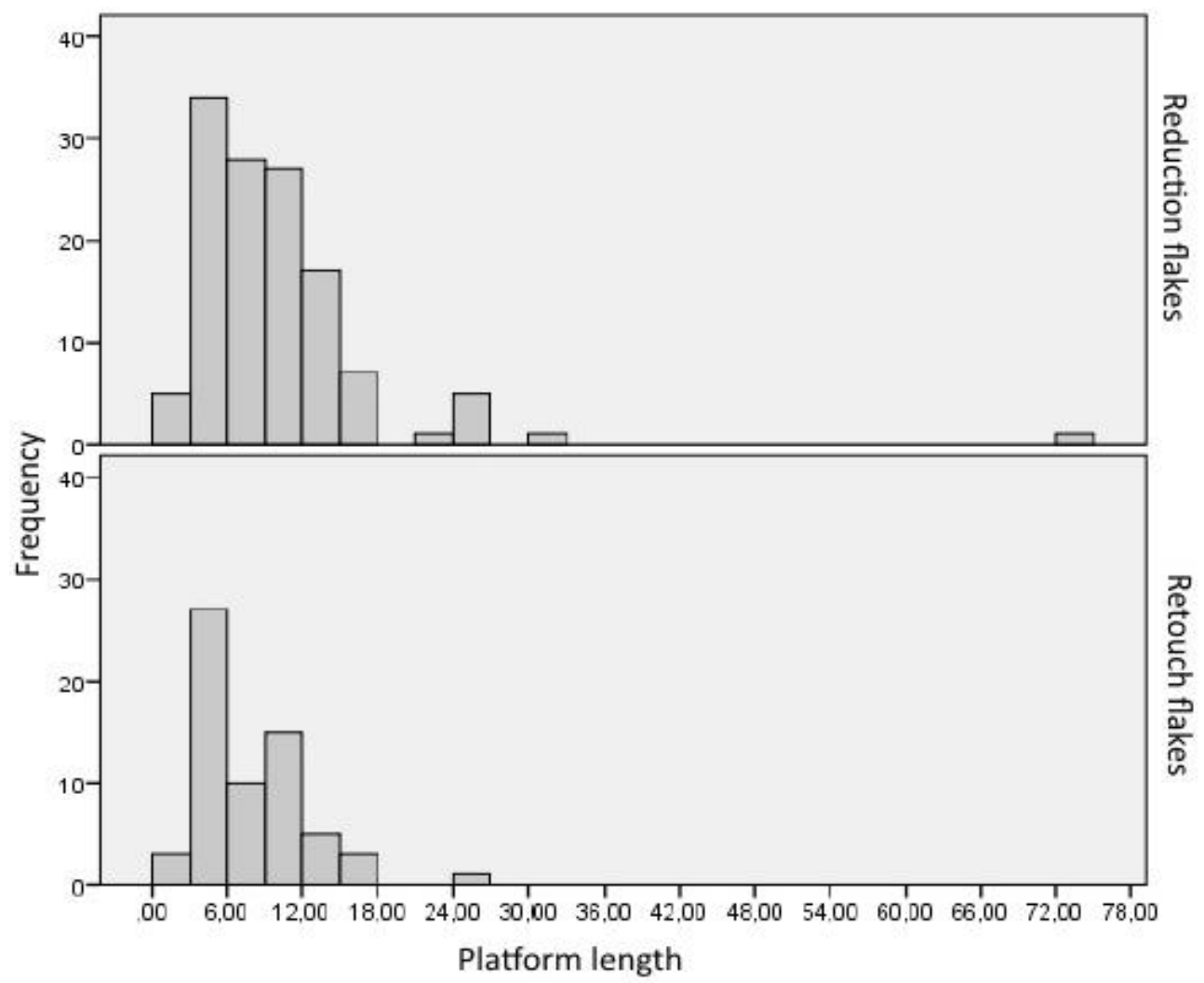

Figure 10. Reduction and retouch flakes platform length.

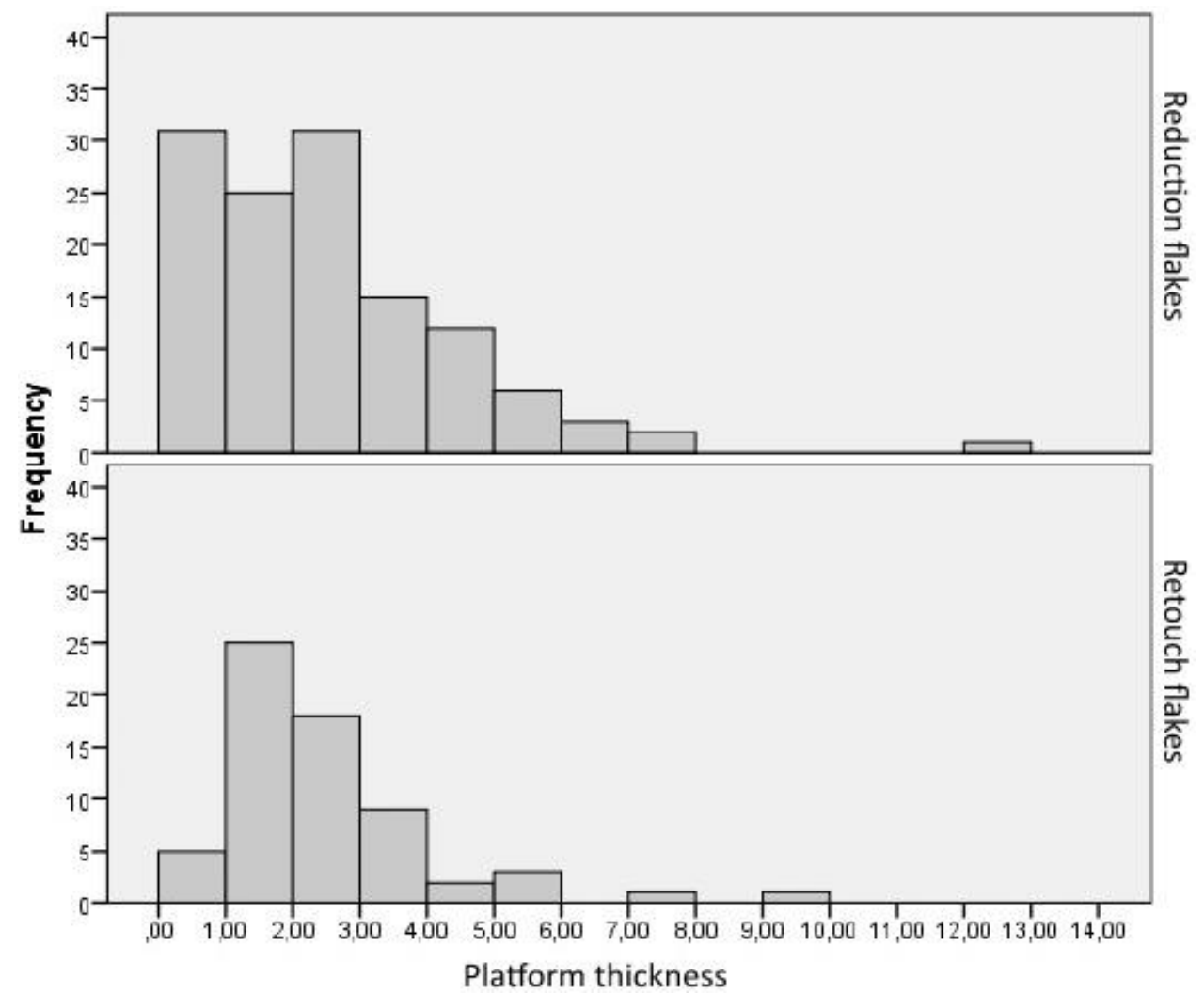

Figure 11. Reduction and retouch flakes platform thickness. 

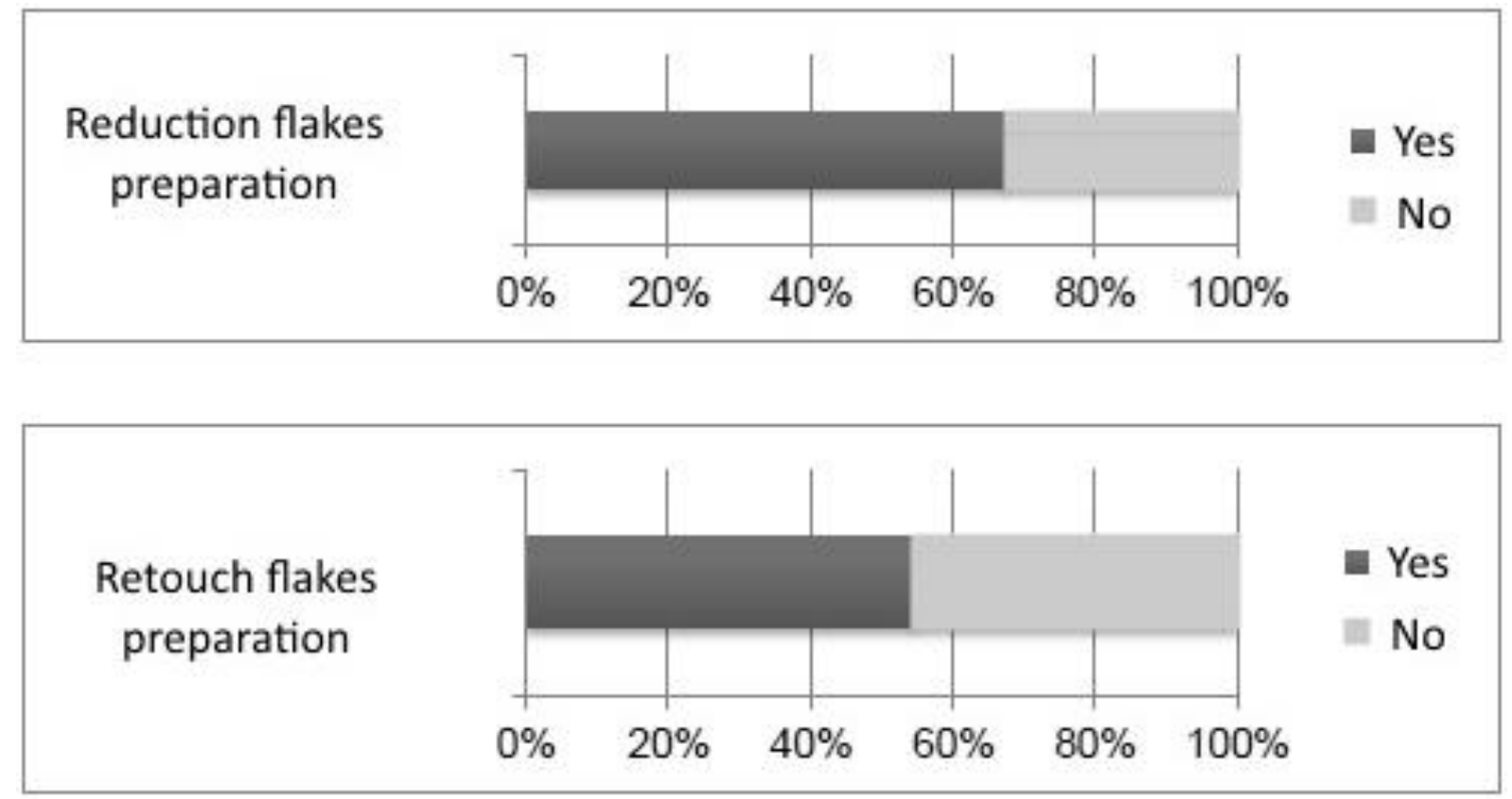

Figure 12. Reduction and retouch flakes platform preparation.

Thirty per cent of the reduction flakes have a lip in the cornice between the platform and the positive face (Figure 13). It means the reduction flakes could be made through other flaking techniques that do not include (or exclude) hard percussion.
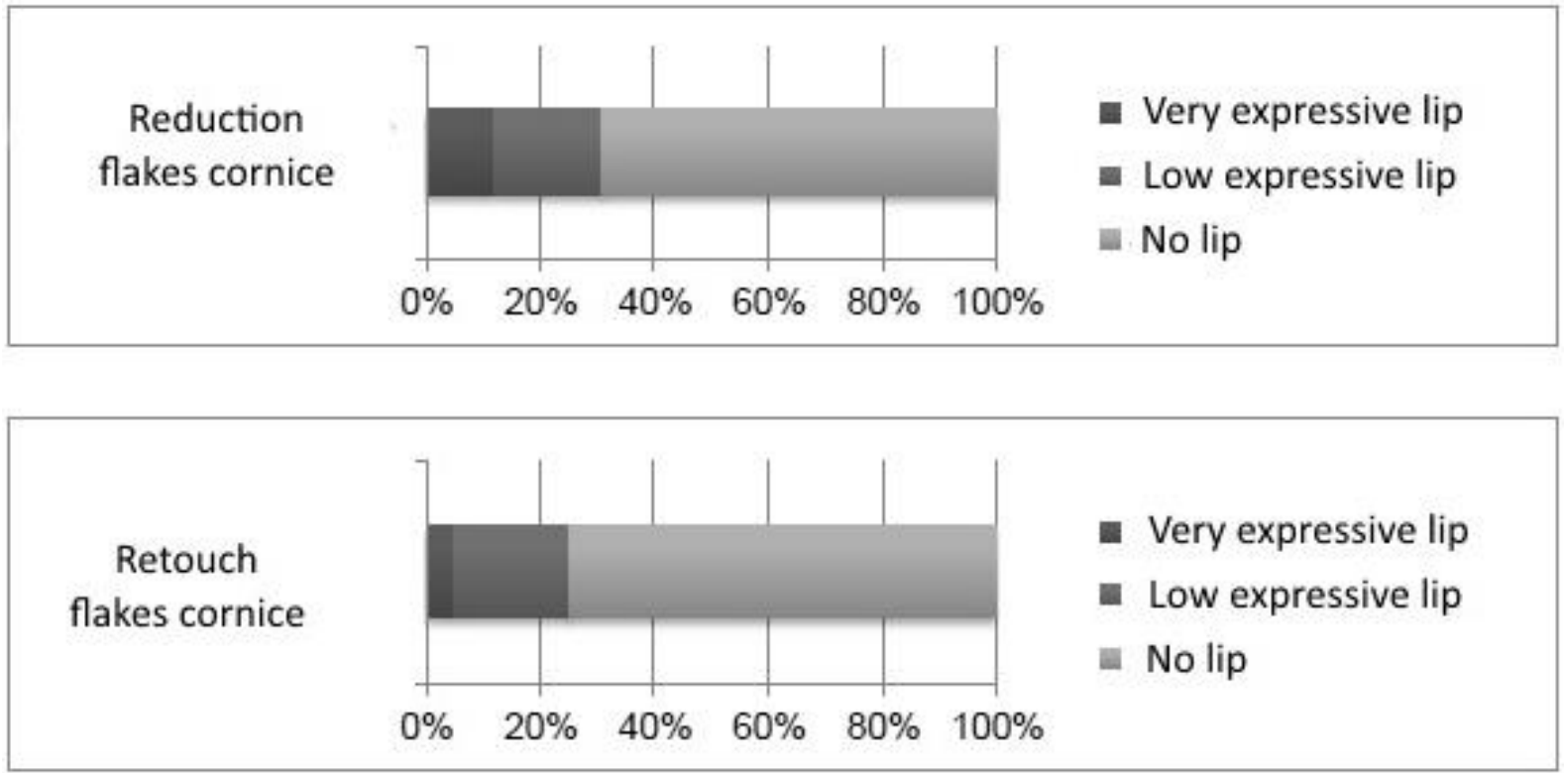

Figure 13. Reduction and retouch flakes cornice.

The angles vary between $110^{\circ}$ and $135^{\circ}$, which means the angles between both faces of the artifacts are between $45^{\circ}$ and $70^{\circ}$ (Figure 14).

The upper face of the flakes mostly have between 2 and 5 flake negatives (preparation negatives not included), organized like the following schemes:

- One vertical rib which guided the flaking.

- "Y" like form organization,

- Inverted "Y" like organization,

- Two vertical ribs 
- Two vertical ribs, plus one horizontal rib.

These flakes mostly have quadrilateral, blade and round shapes; and sometimes they are overshot-like (when it takes of a piece of the other side of the artifact, but in the same face).

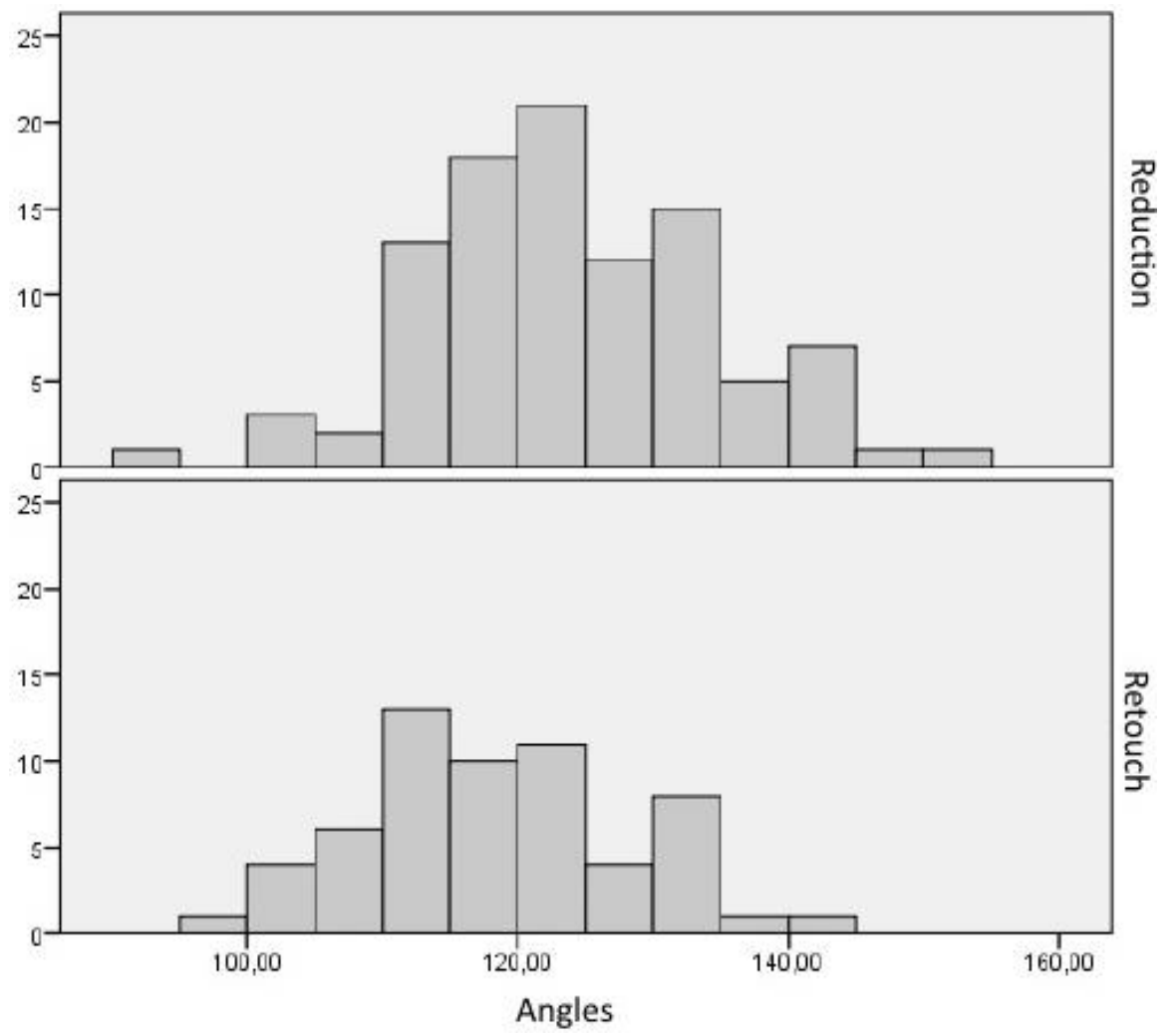

Figure 14. Reduction and retouch flakes angles.

The reduction flakes mostly have a concave side view, and it implicates the artifacts have at least one convex face (Figure 15).
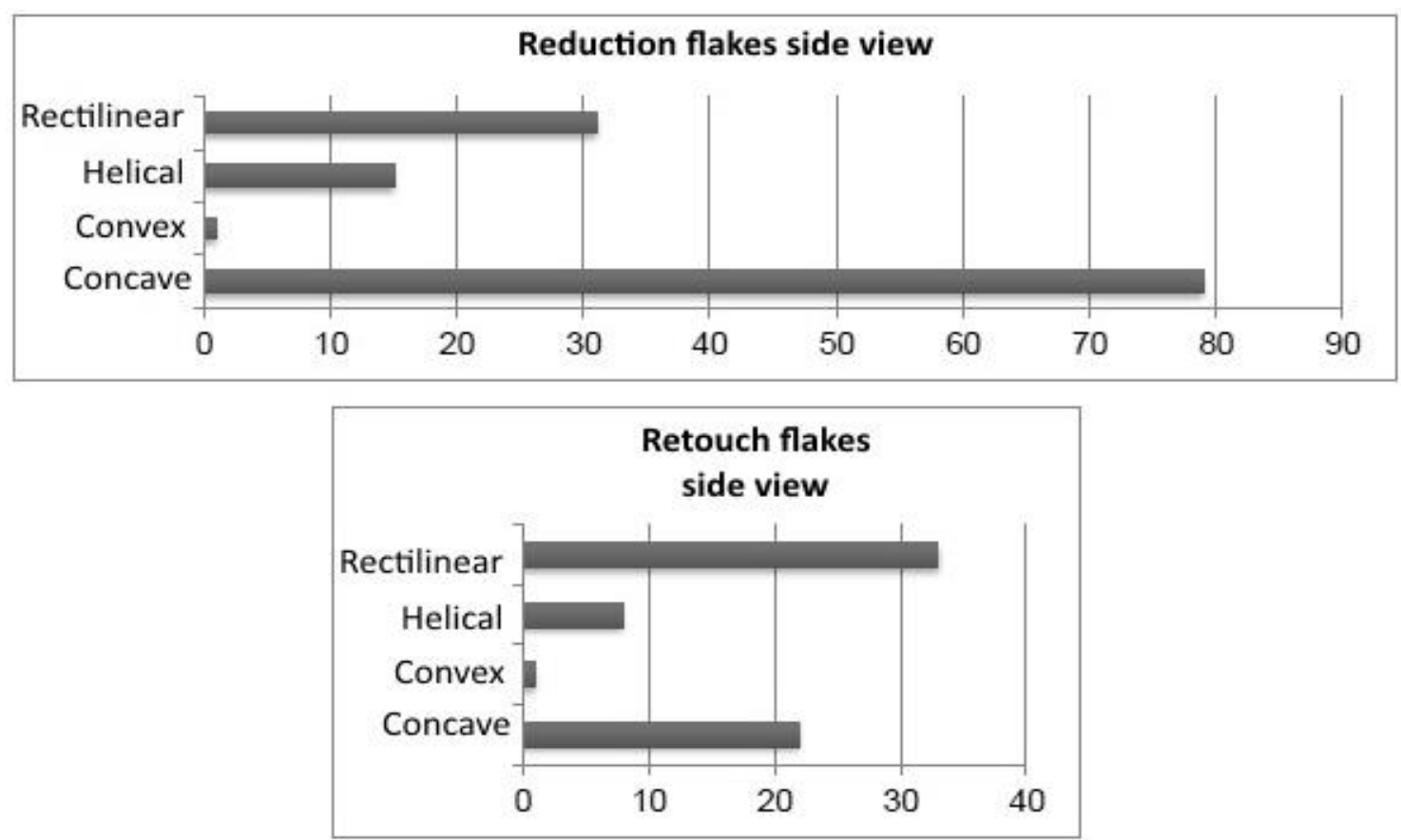

Figure 15. Reduction and retouch flakes side views. 


\subsection{Retouch}

The general measures of the retouch flakes are between 9 15 mm length and width, and $1 \sim 3$ thick. There is no correlation between the measures.

Half of the flakes have prepared platforms, with round, comma and wing shapes. The length varies a lot, between 3 and $12 \mathrm{~mm}$, and the thickness just between 1 and $3 \mathrm{~mm}$. The length and the thickness of the platforms may be correlated $\left(\mathrm{R}^{2}=57.9 \%\right)$ (Figures $7,8,9$ and 16).

\section{Retouch flakes measures corelation}

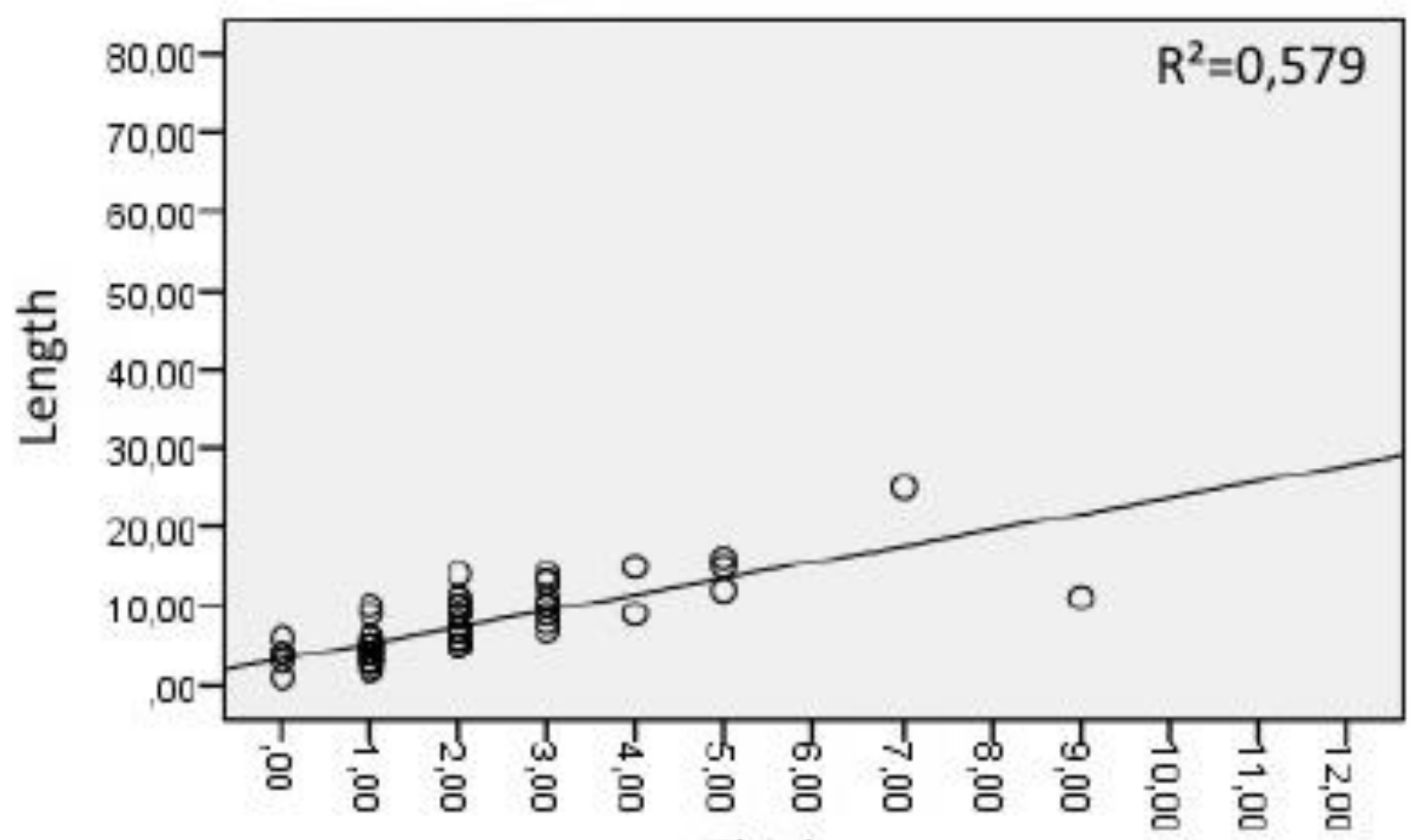

Thickness

Figure 16. Coefficient of determination: $\mathrm{R}^{2}$ Correlation of retouch flakes length and thickness.

Twenty five per cent of the retouch flakes have a lip between the platform and the positive face, and a bit higher tendency to present low expressive bulbs. Once more it means other techniques but hard percussion could have been used once in a while (Figure 13).

The angles between the platform and the positive face of the flakes vary between $105^{\circ}$ and $125^{\circ}$, which means the artifacts edges may have angles between $55^{\circ}$ and $75^{\circ}$ (Figure 14 ).

These flakes tend to have a rectilinear and sometimes concave plan view, which means the edges of the artifacts are mostly plan and convex (Figure 15).

The upper face of the flakes tend to present 2 or 3 flake negatives (preparation negatives not included), and they are organized having one or two vertical ribs. The flakes have mostly quadrilateral or round shapes; and sometimes are reflected.

The main identified tendencies values are exposed in Table 4. Measures and features with no identified tendencies were not considerate. 
Table 4. Main identified tendencies at Gruta das Araras Rockshelter lithic residues.

\begin{tabular}{|c|c|c|}
\hline Flake category & $\begin{array}{l}\text { Identified measures and } \\
\text { features tendencies }\end{array}$ & Tendency values \\
\hline core flaking / debitage & length-thickness correlation & average high \\
\hline core flaking / debitage & $\begin{array}{l}\text { platform's length-thickness } \\
\text { correlation }\end{array}$ & average high \\
\hline core flaking / debitage & platform/positive face angle & $100^{\circ}-120^{\circ}$ \\
\hline core flaking / debitage & $\begin{array}{l}\text { number of superior face } \\
\text { negatives }\end{array}$ & $1-5$ \\
\hline core flaking / debitage & $\begin{array}{l}\text { organization of superior } \\
\text { faces negatives }\end{array}$ & one vertical rib \\
\hline core flaking / debitage & flakes forms & blade; quadrilateral \\
\hline reduction / façonnage & flake length & $15-30 \mathrm{~mm}$ \\
\hline reduction / façonnage & flake width & $10-30 \mathrm{~mm}$ \\
\hline reduction / façonnage & flake thickness & $1-7 \mathrm{~mm}$ \\
\hline reduction / façonnage & platform preparation & high tendency \\
\hline reduction / façonnage & platform shapes & linear; round; "coma" shape \\
\hline reduction / façonnage & platform length & $3-15 \mathrm{~mm}$ \\
\hline reduction / façonnage & platform thickness & $0-3 \mathrm{~mm}$ \\
\hline reduction / façonnage & platform/positive face angle & $110^{\circ}-135^{\circ}$ \\
\hline reduction / façonnage & flake side view & concave \\
\hline reduction / façonnage & $\begin{array}{l}\text { number of superior face } \\
\text { negatives }\end{array}$ & $2-5$ \\
\hline reduction / façonnage & organization of superior & one vertical rib; "y" like form \\
\hline & faces negatives & $\begin{array}{l}\text { organization; inverted y like } \\
\text { organization; two vertical ribs; two } \\
\text { vertical ribs, plus one horizontal rib. }\end{array}$ \\
\hline reduction / façonnage & flakes forms & quadrilateral; blade; round \\
\hline retouch & flake length & 9-15 mm \\
\hline retouch & flake width & 9-15 mm \\
\hline retouch & flake thickness & $1-3 \mathrm{~mm}$ \\
\hline retouch & platform preparation & high tendency \\
\hline retouch & platform shapes & $\begin{array}{l}\text { round; "comma" shape; "wings" } \\
\text { shape }\end{array}$ \\
\hline retouch & platform length & $3-12 \mathrm{~mm}$ \\
\hline retouch & platform thickness & $1-3 \mathrm{~mm}$ \\
\hline retouch & $\begin{array}{l}\text { platform's length-thickness } \\
\text { correlation }\end{array}$ & average \\
\hline retouch & platform/positive face angle & $105^{\circ}-125^{\circ}$ \\
\hline retouch & flake side view & rectilinear; plan \\
\hline retouch & $\begin{array}{l}\text { number of superior face } \\
\text { negatives }\end{array}$ & $2-3$ \\
\hline retouch & $\begin{array}{l}\text { organization of superior } \\
\text { faces negatives }\end{array}$ & one vertical rib; two vertical ribs \\
\hline retouch & flakes forms & quadrilateral; round \\
\hline
\end{tabular}

\subsection{Artifacts}

The small quantity of formal artifacts in the assemblage make it impossible to make a general description of them. Only seven artifacts, most of them broken, were identified. However, other sites of the same archaeological complex area have enough formal artifacts to be analyzed, as Lourdeau (2010) did with Diogo Lemes Rockshelter. 
The few formal artifacts found in the excavation, with exception of the only one made on flint, present the same features tendencies though to present in the residues analyzed. Also, the limaces have more than one functional edge, as it happens in usual Itaparica limaces, probably used like scrapers (Figures 17 and 18).
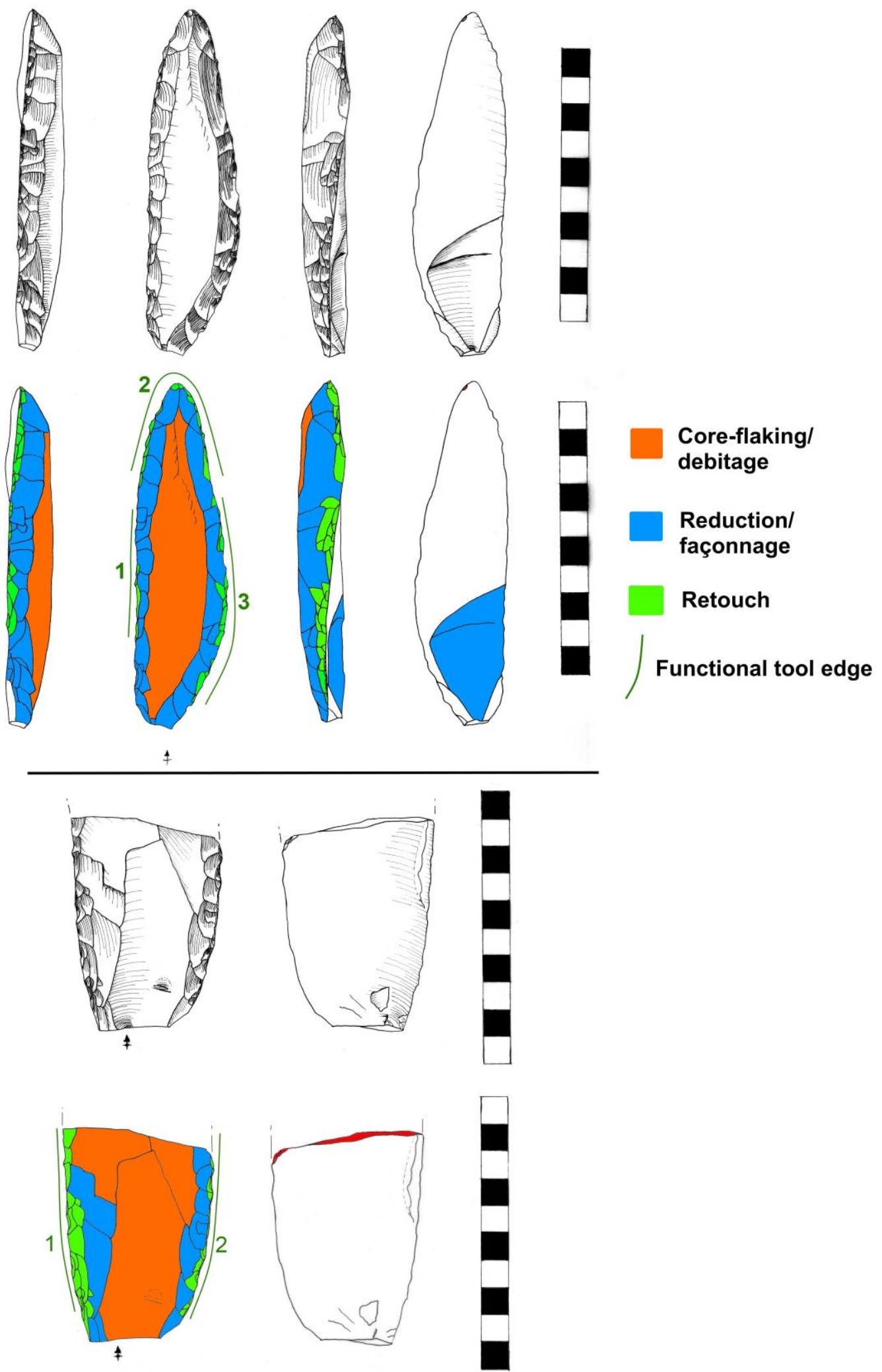

Figure 17. Limaces from Gruta das Araras site. The lower limace is broken at the distal portion. Drawing by the author. 


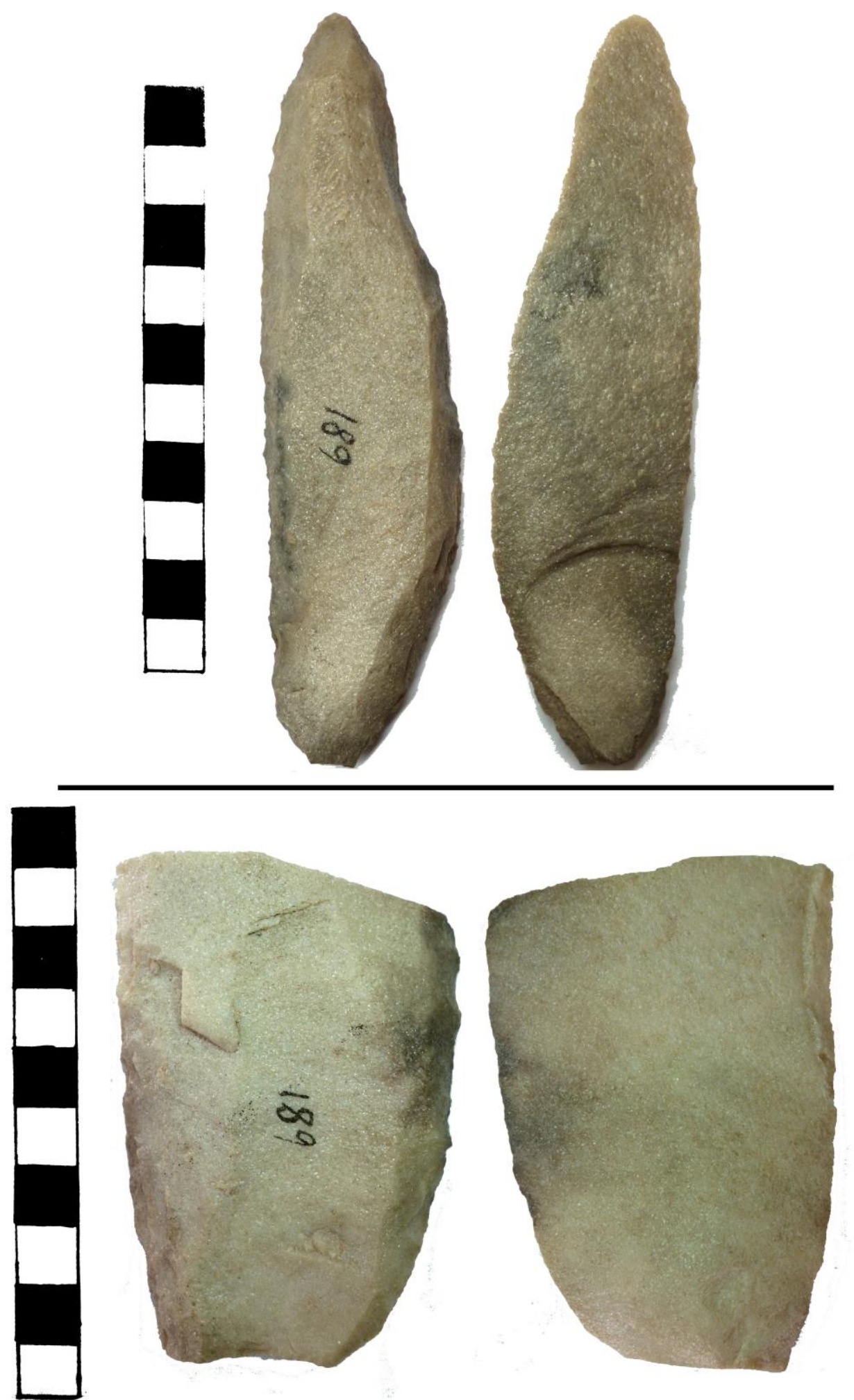

Figure 18. Limaces from Gruta das Araras site. The lower limace is broken at the distal portion. Photos by the author.

\section{Final considerations}

The results corroborate that Itaparica industry is based on a large production of limaces by core-flaking of thick blades and unifacial reduction and retouch. However, detailed features of the flakes of other Itaparica industry sites are needed to be analyzed, so we would 
be able to see tendencies and variability of flaking methods and techniques at this industry. At this point, these results corroborate previous technological researches of the Itaparica industry (Fogaça 2001; 2003; Fogaça \& Lourdeau 2008; Lourdeau 2010; 2012).

The results corroborate that the site were, at that period, used as a lithic workshop (Schmitz, 1989; 2004), possibly mostly to the large production of limaces.

These data also contribute to the idea of unrelated technologies between Clovis industry (once though as the oldest one of the Americas) and Itaparica industry, once they have no similarity, besides a short contemporaneous existence (Araujo et al. 2012; Araujo 2015).

More technological analysis of the lithic formal artifacts, cores and residues are necessary in Itaparica industry sites all over the Brazil central plateau, if we aim to confirm the presence of a same (or similar) technology in those sites during the Pleistocene-Holocene transition and Early Holocene. Also, the application of this study approach is suggested in lithic studies in South America, aiming to compare lithic industries of different regions and different periods. Papers about bifacial industries in Southern Brazil, and microlithic industries in Southeastern Brazil, both also from Pleistocene-Holocene transition, are upcoming soon, aiming to present new data for comparison.

\section{Acknowledgements}

We would like to thank Dr. Pedro Ignácio Schmitz (UNISINOS) for allowing the study of Gruta das Araras Rockshelter lithic material; to Dr. Astolfo Araujo (MAE-USP) for supervising the research; to Marina Gratão (IB-USP) for language revision; and to the Coordenação de Aperfeiçoamento de Pessoal de Nível Superior (CAPES) for funding.

\section{References}

Araujo, A. G. 2015, On Vastness and Variability: Cultural Transmission, Historicity, and the Paleoindian Record in Eastern South America. Anais da Academia Brasileira de Ciências, 87(2): 1239-1258. doi:10.1590/0001-3765201520140219

Araujo, A. G., Neves, W. A., \& Kipnis, R. 2012, Lagoa Santa Revisited: An Overview of the Chronology, Subsistence, and Material Culture of Paleoindian Sites in Eastern Central Brazil. Latin America Antiquity, 23(4): 533-550. doi:10.7183/1045-6635.23.4.533

Boëda, E. 1997, Technogenèse de Systèmes de Production Lithique au Paléolithique Inférieur et Moyen e Europe Occidentale et au Proche-Orient. PhD Dissertation. Université de Paris-X-Nanterre, Paris. 173 p. (in French) ("Technogenesis of Lithic Produciton Systems at Lower and Medium Paleolithic in Western Europe and in Near East")

Calderon, V. 1973, A Pesquisa Arqueológica Nos Estados da Bahia e Rio Grande do Norte. Dédalo, 9(17-18): 25-32. (in Portuguese) ("The archaeological research in Bahia and Rio Grande do Norte states")

Danzeglocke, U., Jöris, O. \& Weninger, B. 2007, CalPal Online. Retrieved January 2014. URL: http://www.calpal-online.de/

Dauvois, M. 1976, Precis de Dessin Dynamique et Structural des Industries Lithiques Préhistoriques. Fanlac: Périgueux. 263 p. (in French) ("Dynamic and Structural Drawing precise of Prehistoric Lithic Industries")

Fogaça, E. 2001, Mãos para o pensamento. A variabilidade tecnológica de indútrias líticas de caçadores-colectores holocênicos a partir de um estudo de caso : as camadas VIII e VII 
da Lapa do Boquete (Minas Gerais, Brasil) - 12.000 / 10.500 B.P. PhD dissertation. Porto Alegre: Pontificia Universidade Católica do Rio Grande do Sul. 642 p. (in Portuguese) ("Hands for thought. Holocene hunther-gatherers technological variability from a study case: Levels VIII and VII from Lapa do Boquete rockshelter (Minas Gerais, Brazil) - 12.000 / 10.500 B.P.”)

Fogaça, E. 2003, Instrumentos líticos unifaciais da transição Pleistoceno-Holoceno no Planalto Central do Brasil: individualidade e especificidade dos objetos técnicos. Canindé, 3: 9-35. (in Portuguese) ("Unifacial lithic tools from Pleistocene-Holocene Transition in Brazil Central Plateau: Technic objects individuality and specifity")

Fogaça, E., \& Boëda, E. 2006, A Antropologia das Técnicas e o Povoamento da América do Sul Pré-Histórica. Habitus, 4(2): 673-684. (in Portuguese) ("The anthropology of techniques and prehistoric population of South America")

URL: http://seer.ucg.br/index.php/habitus/article/view/196

Fogaça, E., \& Lourdeau, A. 2008, Uma abordagem tecno-funcional e evolutiva dos instrumentos plano-convexos. FUMDHAMentos, 7: 260-347. (in Portuguese) (“A technofunctional an evolutive approach of plan-convex tools")

Inizan, M.-L., Reduron-Ballinger, M., Roche, H., \& Tixier, J. 1995, Technologie de la Pierre Taillé.CREP, Paris. 122 p. (in French) ("Flaked stone technology")

Leroi-Gourhan, A. 2002, O Gesto e A Palavra, 2 - Memória e Ritmos. (Portuguese ed.) Lisboa: Edições 70. 245 p. (in Portuguese) ("The gesture and the word, 2 - memory and rhytms")

Lourdeau, A. 2010, Le Technocomplexe Itaparica. Définition Techno-Fonctionelle des Industries à Pièces Façonnées Unifacialement à une Face Plane dans le Centre et le Nord-Est du Brésil Pendant la Transition Pléistocène-Holocène et l'Holocène Ancien. Paris: Université Paris Ouest Nanterre La Defense. 477 p. (in French) ("The Itaparica technocomplex. Technofunctional definition of the one opposite plan face unifacial reduction pieces in Center and Northeastern Brazil during Pleistocene-Holocene transition and Early Holocene")

Lourdeau, A. 2012, The Itaparica Technocomplex: The First Conspicuous Settlement of Central and Northeastern Brazil from a Technological Perspective. In Southbound: Late Pleistocene peopling of Latin America (Miotti L.L., Salemme M., Flegenheimer N., \& Goebel T. Eds.), College Station, Texas: p. 53-56

Mauss, M. 2003, Sociologia e Antropologia. (Brazilian ed.) São Paulo: Cosac Naifyi. 536 p. (in Portuguese) ("Sociology and Anthropology")

Pelegrin, J. 1997, Les Techniques de Débitage Laminaire au Tardiglaciaire: Critères de Diagnose et Quelques Réflexions. In: Table-ronde de Nemours - L'Europe Centrale et Septentrionale au Tardiglaciaire. Paris: Mémoires du Musée de Préhistoire d'lle de France. p. 73-86. (in French) (The laminar core-flaking techniques at Tardiglaciaire: Diagnosis criteria and some reflections")

Piel-Desruisseaux, J. L. 1989, Instrumental pré-histórico. Forma, Fabricación, Utilización.Masson, Barcelona, 279 p. (in Spanish) ("Prehistoric instrumental. Form, fabrication, utilization")

Rigaud, A. 1977, Analyses Tipologique ét Technologique des Grattoirs Magdaleniéns de la Garenne à Saint Marcel (Indre). Gallia Préhistoire, p. 01-43. (in French) (“Typological 
na technological analysis of Magdalenian caves from Garenn to Saint Marcel (Indre)") doi:10.3406/galip.1977.1547

Roche, H., \& Tixier, J. 1984, Tecnologia Lítica: A Questão dos Acidentes de Lascamento. Revista de Pré-história, USP, VI. 256-257 (in Portuguese) ("Lithic technology: The flaking accidents question")

Rodet, M. J., Duarte-Talim, D., \& Barri, F. 2011, Reflexões sobre as primeiras populações do Brasil Central: "Tradição Itaparica". Habitus, 9(1): 81-100. (in Portuguese) (Reflections on the first Central Brazil populations: 'Itaparica tradition"')

URL: http://seer.ucg.br/index.php/habitus/article/view/2211/0

Schmitz, P. I. 1980, A Evolução da Cultura no Sudoeste Goiano. Pesquisas - Antropologia, 31: 185-225. (in Portuguese) ("The evolution of culture in southwestern Goiás state")

Schmitz, P. I., Barbosa, A. S., Jacobus, A. L., \& Ribeiro, M. B. 1989, Arqueologia nos Cerrados do Brasil Central: Serranópolis I. Pesquisas - Antropologia, 44. p. 208. (in Portuguese) ("Archaeology in Brazil Central cerrados: Serranópolis I")

Schmitz, P. I., Rosa, A. O., \& Bitencourt, A. L. 2004, Arqueologia nos Cerrados do Brasil Central. SERRANÓPOLIS III. Pesquisas - Antropologia, 60. p. 1-286. (in Portuguese) ("Archaeology in cerrados of Central Brazil: Serranópolis III")

Tixier, J. 2012, A Method for the Study of Stone Tools - Méthode pous l'Étude des Outillages Lithiques. Luxemburgo: CNRA-MNHA. 195.

Vaughan, P. 1983, La Fonction des Outils Préhistoriques. La Recherche, p. 1226-1234. (in French) ("The prehistoric tools function")

White, J. P., \& Thomas, D. H. 1972, What Mean These Stones? Ethno-Taxonomic Models and Archaeological Interpretations in the New Guinea Highlands. In: Models in Archaeology. (Clarke, D.L. Ed.), Methuen, London, p. 275-308. 